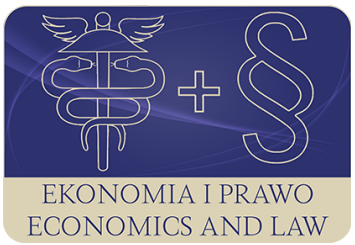

EKONOMIA I PRAWO. ECONOMICS AND LAW

Volume 18, Issue 4, December 2019

p-ISSN 1898-2255, e-ISSN 2392-1625

www.economicsandlaw.pl

EKONOMIA I PRAWO
ECONOMICS AND LAW

ORIGINAL ARTICLE

received 30.03.2019; revised 12.12.2019; accepted 31.12.2019

Citation: Czajkowska, A. (2019). The role of financing innovative technological investments with credit for technological innovations. Ekonomia i Prawo. Economics and Law, 18(4): 413-423.

\title{
The role of financing innovative technological investments with credit for technological innovations
}

\author{
AGNIESZKA CZAJKOWSKA \\ University of Lodz, Faculty of Economics and Sociology, Institute of Finance, Centre for Corporate \\ Finance, ul. Rewolucji 1905 r. 39, 90-255 Łódź, Poland \\ ๑agnieszka.czajkowska@uni.lodz.pl \\ (D) orcid.org/0000-0002-7445-887X
}

\begin{abstract}
Motivation: Credit for technological innovations is implemented under competition projects in Submeasure 3.2.2 of Innovation support for enterprises of Smart Growth Operational Programme 2014-2020. It is a follow-up to the measure implemented under the Innovative Economy programme. The support granted in the form of so-called ‘technology bonus' allows to partially repay a credit for technological innovations granted by a commercial bank. It is an instrument of financial support aimed at increasing the innovativeness and competitiveness of micro-, small and medium-sized enterprises (MSME). The innovativeness of Polish MSME is at a very low level, compared to other EU countries., Therefore, it seems necessary to implement various instruments of support and stimulation of investment in innovative technologies.

Aim: assessment of credit procedures and possibilities of financial support MSME activity from a credit for technological innovations. To do this, an analysis is needed of the procedure and funding rules for technological investments with POIR resources. Besides, the literature of the subjects as well as the most important findings and statistics have been reviewed and evaluated.

Results: presentation of the specificity of the credit in the case of technological innovations, including the obtainment of a technology bonus, assessment of the innovative activity of MSME, as well as the state of financing innovations and technological investments of MSME, including indication of limitations in this respect.
\end{abstract}


Keywords: credit for technological innovations; micro, small and medium-sized enterprises; technology investment; technology bonus

JEL: G19; G20; G21; G29; O32; O33; O38; O39

\section{Introduction}

The MSME sector seeks tools to support the innovation policy, particularly financial instruments which would be readily available and simple. One of them is Smart Growth Operational Programme 2014-2020, whose goal is to support the innovativeness and competitiveness of Polish economy. Credit for technological innovations has been isolated as a sub-measure within Priority Axis 3 (support for innovations in enterprises). Investing in innovations, accompanied by a higher risk level and a higher demand for capital, is a major challenge of entrepreneurs today.

\section{Literature and reports review}

\subsection{Bank credits as a source of financing innovations for MSME}

The traditional form of financing innovations are bank investment credits. They are a major source of financing, particularly for small enterprises (Kerr \& Nanda, 2015, pp. 453-455). They can finance product and process innovations of high market maturity e.g. creating a technological line using one's own technology or one acquired externally with all its infrastructure.

Bank credit plays an important role in financing innovative businesses and is the main source of financing young and small companies in Europe (Colombo \& Grilli, 2007, pp. 25-46; Giudici \& Paleari, 2000, pp. 37-53) and the USA (Robb \& Robinson, 2014, pp. 153-179).

Bank credit is the most popular source of borrowed capital for MSME. In 2015 most of MSME capital expenditures were financed with own resources (60.3\%), 21.1\% with domestic loans and $7.4 \%$ with foreign funds. Other sources of funding were less significant. The bigger an enterprise the bigger the engagement of one's own resources in financing an investment (Łapiński et al., 2018, pp. 26-27) (table 1). Despite the growing offer of alternative forms of financing, bank funding remains the most common form of business support (Koziol \& Pitera, 2018, p. 152). This is the 'traditional picture of financing an enterprise', in which its own sources play the most important role and bank credit is the external funding source (Różański, 2015, p. 499). The use of credit for investment outlay in MSME is 2.5 times higher than in big companies. 


\subsection{The essence of innovation and specification of technological investment}

The meaning of 'innovation' is wide. It may refer to technological improvement but it may also have a social dimension. Its multidimensionality is reflected in definitions found in the literature. Innovation (from Latin innovatio, 'renewal') is a sequence of activities which result in new or improved products, technological processes or organizational systems. In economy the term was introduced by J.A. Schumpeter (Wiśniewska, 2015, p. 10).

According to the Oslo Manual: 'an innovation is the implementation of a new or significantly improved product (good or service), or process, a new marketing method, or a new organisational method in business practices, workplace organisation or external relations' (OECD \& Eurostat, 2005, p. 18). In a company innovation is each justified and beneficial change in any area of its operation which arose in the company or its environment (Krawczyk-Sokołowska, 2014). A condition for a new solution to become an innovation is its commercialization (Carlino \& Kerr, 2015, pp. 349-404). Innovations result not only from actions of single entities but also from the collective learning process and intensive interactions between those (Elg, 2014, p. 6).

Innovativeness is the ability to permanently seek and use in practice new ideas and inventions but also research findings and effects of development work (Duraj \& Papiernik-Wojdera, 2010, p. 61). Companies treat innovative activity as a factor significant for their own development (Starzyńska, 2015, p. 227). Innovativeness is connected with the ability to generate and use knowledge and with creativity and entrepreneurship (Howells, 2002, pp. 871-884).

An effective way for a company to enhance its productivity and competitiveness on the market and - as a result - its innovativeness is investing in new technologies. This proves effective in countries like Poland, which are currently catching up technologically with developed countries.

Technological innovations are regarded as the most important as they yield the highest added value and the highest income to the company, although being the most expensive. They contribute to the development of products and services. They are based on research and its findings. This type of innovation is often a source of organizational and process innovations (Portal Innowacji, 2018).

According to Rules of the competition for a credit for technological innovations 'a technological investment means 1) purchase of a new technology, 2) its implementation and resulting initiation of production of new or significantly improved if compared to goods, processes or services hitherto produced in the Republic Poland, or 3) implementation of one's own technology and resulting initiation of production of goods, processes or services hitherto produced in the Republic of Poland' (BGK, 2018b, $\mathbb{S} 1 \mathrm{pt} 8$ ). The technology to be implemented must be in the form of: industrial property right, outcome of development work, outcome of industrial research or non-patented technological knowledge (Serwis Programu Inteligentny Rozwój, 2018). 
The implementation of a technology is to consist in such actions on the part of the entrepreneur, whereby the new technological idea will be carried out by creating a technological base with which that technology can be put in practice. The expenses which qualify for a technological investment include (BGK, 2018b):

- purchase of undeveloped or developed property, including the right of perpetual usufruct;

- purchase and production, as well as the costs of their installation and launch;

- purchase of existing fixed assets, as well as the costs of their installation and launch;

- purchase of works and building materials for new buildings or for extension or modernization of the existing building, structures or parts thereof;

- costs of letting or lease of land, buildings and structures or parts thereof;

- costs of studies, surveys or technical design by external consultants which are indispensable to implementation of a new technology.

\subsection{Innovative activity of Polish MSME sector in comparison with}

\section{EU}

Polish companies are investing more and more in innovation and co-operate with other entities in this field. In 2010-2016 their R\&D expenditures against GDP trebled from $0.19 \%$ in 2010 to $0.63 \%$ in 2016, and by 9 billion PLN in absolute terms. In 2016 R\&D expenditures were increased by $40 \%$ compared to 2015. Simultaneously, an increase was seen in the number of companies investing in R\&D, reaching 4250 in 2016 (14\% more) (Zakrzewski, 2017, p. 5).

The latest data provided by GUS (Central Statistical Office) show that the percentage of innovation active enterprises in 2014-2016 was 20.3\% and $1.4 \mathrm{pp}$ higher than in 2013-2015 (Dmitrowicz-Życka et al., 2018, p. 9). In 2016 companies in Poland allocated over 39 million PLN in innovation, which was $11 \%$ less than in 2015 (Nieć, 2018a, p. 46).

EU data from 2017 on innovative activity indicate a general drop and this adverse trend was seen also in Poland. The percentage of innovative companies was $21 \%$, second to last in EU, before Romania. The average innovation expenditure of a company was 728000 EUR and was 22\% lower than in the average EU company (Skowrońska \& Tarnawa, 2018, p. 8). In Poland implemented innovations are mainly technological (16\% of active innovative enterprises), with $13 \%$ non-technological. The biggest barrier to internal innovations in non-innovative companies is that they cannot be financed from internal sources - $28 \%$ (Nieć, 2018b, p. 37).

Poland's relatively low position in international rankings means that there is still potential to be realized. Many changes in the innovation support policy are taking place which should be beneficial to economic growth (Growiec \& Sławiński, 2016, p. 28). 
Poland's position in international comparisons of innovativeness remains a challenge. In the Global Innovation Index 2017 Poland ranks 38 (Business Insider Polska, 2018) and in 201839 out of 126. In the lead is Switzerland, followed by the Netherlands and Sweden (Ministry of Entrepreneurship and Technology, 2018, pp. 41-42). The second prestigious ranking - Bloomberg Innovation Index 2018 shows Poland as 21st out of 80 (Business Insider Polska, 2018).

In European Innovation Scoreboard 2017 Poland ranked 25 out of 28 (two places down compared to 2016) (Wąsowski, 2018). In 2018 Poland stayed in the 25th place in the group of so-called moderate innovators (Ministry of Entrepreneurship and Technology, 2018, p. 9).

\section{Rules for credit financing of technological innovations}

Sub-measure 3.2.2 Credit for technological innovations is implemented under Priority Axis 3: Support for Innovation in Enterprises POIR 2014-2020. It is an instrument of financial support intended to increase innovativeness and competitiveness of MSME by enabling them to implement technological innovations which are the effect of their own R\&D work or are purchased under the project. The beneficiaries of the support can be registered business entities operating in Poland which meet the criteria for MSME and are creditworthy (BGK, 2018b; Ministry of Infrastructure and Development, 2015). The key criteria for selecting the projects to be financed require that the project be launched after the date of application for funding and the implementation be completed within the required timeframe i.e. before 31 December 2023 (Biznes-animator, 2018).

The support for the enterprise is in the form of a 'technology bonus' for partial repayment of the loan granted by a commercial bank for a technological investment. Own resources must be at least $25 \%$ of the eligible costs of a technology investment financed with a technology loan. The bonus is paid in instalments in the course of the project and on its completion as the final payment. The maximum amount of the bonus is 6 million PLN (BGK, 2018b). The overall envelope for financing projects is 550 million PLN (Serwis Programu Inteligentny Rozwój, 2018). Whether the technology bonus gets granted depends on proper calculation of eligible costs which determine the actual amount granted (see scheme 1).

The amount allocated for financing projects in the form of a technology bonus for 2014-2020 is 422 million EUR, of which 42 million EUR for the Mazovia province and 380 million EUR for the remaining provinces (BGK, 2018b). Within this sub-measure until the end of February 2017167 loan agreements were signed, which resulted in the support of a total amount of 615 million PLN (Lisowska, 2017, p. 173). At the beginning of 2018 the situation with innovation loans looked as follows: 1364 applications were submitted for co-financing projects at a total amount of 9.9 billion PLN, with the aid requested at 4.6 billion PLN. 472 loan promises were issued. Ultimately, 1.7 billion PLN was granted as co-funding and 385 agreements were signed. 180 instalments were paid, 73 
projects were concluded and 38 settled (BGK, 2018a, p. 13). Within one year the effectiveness of credit granting doubled, regarding the number of agreements concluded and the value of allocated funds.

The share of a technology bonus regarding the value of eligible costs is allocated in accordance with ceilings laid down in the regional aid map (BGK, 2018b). The level of support, depending on the size of the enterprise, ranges from $20 \%$ to $70 \%$ of elligible costs and up to $50 \%$ of elligible costs of purchase of consultancy services for all (Grupa 4 Fundusze Europejskie, 2018) (table 2).

The loan for technological innovations is granted on market terms i.e. those applicable to investment loans. BGK co-operates with 19 banks, including 15 commercial banks operating in Poland, SGB S.A., PBS S.A., and associated co-operative banks and 2 unaffiliated. Conditions are negotiated between the crediting bank and the credit recipient. The application process consists of 8 stages (unless the application gets rejected at some stage); further procedures are presented in scheme 2 .

Besides the accurate charting of a course for innovation investments, a condition for co-financing is a favourable assessment of creditworthiness of a company. This is not always possible with MSME because of insufficient collateral - or lack thereof - required by the commercial bank. A positive creditworthiness assessment and a loan promise provide the basis for formal assessment of the application form for a technological bonus. Once the formal conditions have been met, the project is next evaluated for its merit, expert judgement and conformity with the competition terms and conditions (Sarniak, 2015, p. 9).

\section{Conclusion}

Innovative MSME in their early stages of development and without a rich credit history or sufficient collaterals have limited access to investment capital. The smallest and youngest companies in Poland encounter barriers in access to bank credit. The main inhibitor of innovation activity for Polish enterprises is lack of funds from internal sources. Recent public intervention in this field has facilitated access to credit considerably. Companies can use preferential credits for implementation of new technologies and innovation investments. The scale of programmes directed at strictly innovative companies is still relatively small. Nevertheless, it is thanks to them that Polish companies are more and more innovative, are getting actively involved in R\&D and are increasingly willing to co-operate with banks.

Credit for technological innovations is a financial instrument intended to support MSME in their innovation activities at various stages of their development. The analysis of sub-measure 3.2.2 POIR shows that the programme is an important source of financing innovation projects. The dynamic growth of the volume of credits granted and used which is presented in the article proves their major role in financing technological innovations. At the same 
time, the analysis of the multi-step loan qualifying procedures reveals the complexity of the application process and varied requirements from entrepreneur borrowers. On the other hand, statistical data confirm that more and more entrepreneurs successfully obtain and pay off those credits using a technological bonus. The author believes that in the future credit for technological innovation may become an effective instrument of the state's pro-innovation policy on condition that this form of financing becomes more popular among credit analysts and that they become directly involved in a campaign promoting this form of credit among innovative entrepreneurs.

\section{References}

BGK. (2018a). Regulamin konkursu w ramach Programu Operacyjnego Inteligentny Rozwój 2014-2020; Oś Priorytetowa III: Wsparcie Innowacji w Przedsiębiorstwach; Dziatanie 3.2: Wsparcie wdrożeń wyników prac B+R, Poddziatanie 3.2.2: Kredyt na innowacje technologiczne; konkurs nr 5, rok: 2018. Retrieved 15.11.2018 from https://www.bgk.pl.

BGK. (2018b). Skorzystaj z Programu: Poddziatanie 3.2.2: Kredyt na innowacje technologiczne PO IR. Retrieved 15.11.2018 from https://www.bgk.pl.

Biznes-animator. (2018). PO IR: poddziatanie 3.2.2.: kredyt na innowacje technologiczne. Retrieved 15.11.2018 from http://www.biznes-animator.pl.

Business Insider Polska. (2018). Polacy to umiarkowani innowatorzy: jak nasi przedsiębiorcy wypadają na tle innych krajów? Retrieved 05.04.2018 from https:// businessinsider.com.pl.

Carlino, G., \& Kerr, W.R. (2015). Agglomeration and innovation. In G. Duranton, J.V. Henderson, \& W.C. Strange (Eds.), Handbook of regional and urban economics. Amsterdam: Elsevier. doi:10.1016/B978-0-444-59517-1.00006-4.

Colombo, M.G., \& Grilli, L. (2007). Funding gaps? Access to bank loans by high-tech start-ups. Small Business Economics, 29(1-2). doi:10.1007/ sil187-005-4067-0.

Dmitrowicz-Życka, K., Konarska-Michalczyk, E., Malesza, A., Orczykowska, M., \& Orzechowska, U. (2018). Innovative activity of enterprises in the years 2014-2016. Retrieved 05.04.2018 from https://stat.gov.pl.

Duraj, J., \& Papiernik-Wojdera, M. (2010). Przedsiębiorczość i innowacyjność. Warszawa: Difin.

Elg, L. (2014). Innovations and new technology: what is the role of research? Implications for public policy. Retrieved 05.04.2018 from https://www.vinnova.se.

Giudici, G., \& Paleari, S. (2000). The provision of finance to innovation: a survey conducted among Italian technology-based small firms. Small Business Economics, 14(1). doi:10.1023/A:1008187416389.

Growiec, J., \& Stawiński, A. (Eds.). (2016). Potencjat innowacyjny gospodarki: uwarunkowania, determinanty, perspektywy. Retrieved 05.04.2018 from https://www.nbp.pl. 
Grupa 4 Fundusze Europejskie. (2018). 3.2.2. PO IR Kredyt na innowacje technologiczne. Retrieved 15.11.2018 from http://www.grupa4.pl.

Howells, J.R.L. (2002). Tacit knowledge, innovation and economic geography. Urban Studies, 39(5-6). doi:10.1080/00420980220128354.

Kerr, W.R., \& Nanda, R. (2015). Financing innovation. Annual Review of Financial Economics, 7(1). doi:10.1146/annurev-financial-111914-041825.

Kielecki Park Technologiczny. (2018). Retrieved 15.11.2018 from http://www. technopark.kielce.pl.

Koziol, K., \& Pitera, R. (2018). Kredyt bankowy jako podstawa zewnętrznego finansowania małych i średnich przedsiębiorstw sektora usług. Studies of the Industrial Geography Commission of the Polish Geographical Society, 32(2). doi:10.24917/20801653.322.10.

Krawczyk-Sokołowska, I. (2014). Regionalne uwarunkowania innowacyjności przedsiębiorstw. Zeszyty Naukowe Polskiego Towarzystwa Ekonomicznego w Krakowie, 15.

Lisowska, R. (2017). Financing innovative activity of small and medium-sized enterprises from the EU funds: financial perspective 2014-2020. Annales Universitatis Mariae Curie-Sktodowska: Oeconomia, 51(6). doi:10.17951/h.2017.51.6.167.

Łapiński, J., Nieć, J. Orłowska, J., \& Zakrzewski, R. (2018). Obraz statystyczny przedsiębiorstw w Polsce. In A. Skowrońska, \& A. Tarnawa (Eds.), Raport o stanie sektora matych i średnich przedsiębiorstw w Polsce. Retrieved 05.04.2018 from https://www.parp.gov.pl.

Ministry of Entrepreneurship and Technology. (2018). Entrepreneurship in Poland. Retrieved 05.04.2018 from https://www.gov.pl.

Ministry of Infrastructure and Development. (2015). From idea to market: Smart Growth Operational Programme 2014-2020. Retrieved 05.04.2018 from https://www.poir.gov.pl.

Nieć, M. (2018b). Ranking przedsiębiorczości w układzie wojewódzkim: wskaźnik syntetyczny. In A. Skowrońska, \& A. Tarnawa (Eds.), Raport o stanie sektora matych $i$ średnich przedsiębiorstw $w$ Polsce. Retrieved 05.04.2018 from https://www.parp.gov.pl.

Nieć, M., (2018a). Innowacyjność przedsiębiorstw. In A. Skowrońska, \& A. Tarnawa (Eds.), Raport o stanie sektora matych i średnich przedsiębiorstw w Polsce. Retrieved 05.04.2018 from https://www.parp.gov.pl.

OECD \& Eurostat. (2005). Oslo manual: guidelines for collecting and interpreting technological innovation data. Paris: OECD and Eurostat. doi:10.1787/9789264013100-en.

Portal Innowacji. (2018) Co to jest innowacja? Retrieved 30.11.2018 from http:// www.pi.gov.pl.

Robb, A.M., \& Robinson, D.T. (2014). The capital structure decisions of new firms. Review of Financial Studies, 27(1). doi:10.1093/rfs/hhs072. 
Różański, J. (2015). Financing of innovation of Eódź region companies. Annales Universitatis Mariae Curie-Sktodowska: Oeconomia, 49(4). doi:10.17951/h.2015.49.4.493.

Sarniak, J. (2015). Kredyt technologiczny jako narzędzie budowania przewagi konkurencyjnej małych i średnich przedsiębiorstw w Polsce. Rynek-Spoteczeństwo-Kultura, 1(13).

Serwis Programu Inteligentny Rozwój. (2018). 3.2 Wsparcie wdrożeń wyników prac $B+R$ / 3.2.2 Kredyt na innowacje technologiczne, Inteligentny Rozwój. Retrieved 15.01.2018 from https://www.poir.gov.pl.

Skowrońska, A. \& Tarnawa, A. (2018). Profile przedsiębiorstw. In A. Skowrońska, \& A. Tarnawa (Eds.), Raport o stanie sektora matych i średnich przedsiębiorstw w Polsce. Retrieved 05.04.2018 from https://www.parp.gov.pl.

Starzyńska, D. (2015). Capital structure of companies and its impact on cooperation with science in the field of innovation: the survey results. Annales Universitatis Mariae Curie-Sktodowska: Oeconomia, 48(4). doi:10.17951/h.2014.48.4.223.

Wąsowski, M. (2018). Innowacyjność: Polska wciąż na szarym końcu. Retrieved 16.05.2018 from https://businessinsider.com.pl.

Wiśniewska, S. (2015). Skuteczność niekomercyjnych instytucji otoczenia biznesu we wspieraniu innowacji marketingowych matych $i$ średnich przedsiębiorstw. Kraków. UE w Krakowie.

Zakrzewski, R. (2017). Sektor MSP w Polsce i UE: podsumowanie. In A. Skowrońska, \& A. Tarnawa (Eds.), Sektor MSP w Polsce i UE. Retrieved 05.04.2018 from https://www.parp.gov.pl.

Zaremba, A. (2016). Program Operacyjny Inteligentny Rozwój. Retrieved 31.03.2019 from http://www.pracodawcy.info.pl.

\section{Acknowledgements}

Author contributions: author has given an approval to the final version of the article.

Funding: this research was funded by the University of Lodz, Faculty of Economics and Sociology, Institute of Finance, Centre for Corporate Finance statutory sources.

Note: the results of this study were presented at 10th International Conference on Applied Economics Contemporary Issues in Economy (June 27-28, 2019, Torun, Poland). 


\section{Appendix}

Table 1.

Sources of financing capital expenditure in companies (excluding micro-enterprises) in 2015

\begin{tabular}{|c|c|c|c|c|c|}
\hline Specification & Total & $\begin{array}{c}\text { SME (excluding } \\
\text { micro-enterprises) }\end{array}$ & Small & Medium & Big \\
\hline total (in mln PLN) & 165413 & 54032 & 16591 & 37440 & 111381 \\
\hline own resources (in \%) & 67.12 & 60.32 & 63.04 & 59.11 & 70.41 \\
\hline budget appropriation (in \%) & 4.07 & 4.51 & 4.27 & 4.62 & 3.85 \\
\hline domestic credits and loans (in \%) & 12.70 & 21.06 & 20.23 & 21.43 & 8.64 \\
\hline \multirow{2}{*}{ foreign direct resources $\begin{array}{l}\text { tota } \\
\text { ban }\end{array}$} & 9.21 & 7.44 & 6.01 & 8.08 & 10.07 \\
\hline & 0.75 & 0.68 & 1.21 & 0.45 & 0.79 \\
\hline other sources (in \%) & 3.69 & 5.80 & 5.88 & 5.77 & 2.66 \\
\hline non-financed expenditures (in \%) & 3.22 & 0.87 & 0.58 & 0.99 & 4.36 \\
\hline
\end{tabular}

Source: Own preparation based on Łapiński et al. (2018, p. 27).

Table 2.

Aid intensity by provinces (in \%)

\begin{tabular}{|c|c|c|}
\hline Region & Micro/Small & Medium \\
\hline \multicolumn{3}{|l|}{ Mazovia province } \\
\hline Warsaw West county & 40 & 30 \\
\hline City of Warsaw (until 31 Dec 2017) & 35 & 25 \\
\hline City of Warsaw (from l Jan 2018) & 30 & 20 \\
\hline other regions of Mazovia & 55 & 45 \\
\hline \multicolumn{3}{|l|}{ other provinces: } \\
\hline Lower Silesia, Silesia, Greater Poland & 45 & 35 \\
\hline $\begin{array}{l}\text { Kujawy-Pomerania, Lubusz, Lodz, Lesser Poland, Opole, Pomerania, Świętokrzyskie, } \\
\text { West Pomerania }\end{array}$ & 55 & 45 \\
\hline Lublin, Subcarpathian, Podlaskie, Warmia-Mazuria & 70 & 60 \\
\hline
\end{tabular}

Source: Own preparation based on BGK (2018b).

Scheme 1 .

Technology bonus in the cost structure of an innovative investment

\begin{tabular}{|c|c|c|}
\hline \multicolumn{3}{|c|}{ total investment } \\
\hline eligible expenses & non-eligible expenses \\
\hline $\begin{array}{c}\text { technology bonus } \\
\text { (75\% of eligible costs) }\end{array}$ & own contribution \\
(25\% of eligible costs and non-eligible costs)
\end{tabular}

Source: Own preparation. 
Scheme 2.

Application process for technology bonus

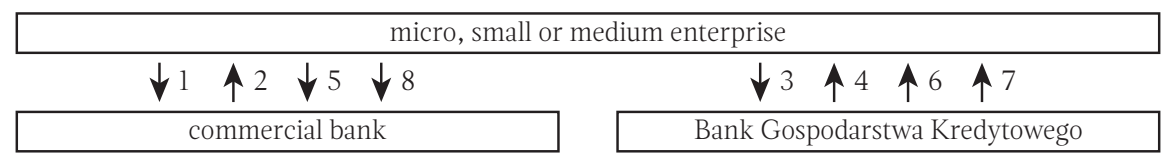

Notes:

1 - the beneficiary submits an application form for a loan for technological innovations at a commercial bank; 2 - the beneficiary receives a loan promise or concludes a conditional agreement with a commercial bank; 3 - the beneficiary submits an application form for co-financing the project at BGK; 4 - BGK grants a promise of a technology bonus (if decided in favour); 5 - the beneficiary concludes a credit agreement with a commercial bank if a promise has been granted; 6 - BGK signs an agreement with the beneficiary for co-financing the project; 7 - BGK pays the technology bonus as intermediate payments during the investment process and as the final payment on conclusion; 8 - repayment is made into the bank account indicated by the crediting bank up to the credit balance on the day of payment of the technology bonus.

Source: Own preparation based on BGK (2018b), Kielecki Park Technologiczny (2018) and Zaremba (2016, pp. 10-11). 
